\title{
A pipa como um fé(i)tiche: passando ao largo de dicotomias`
}

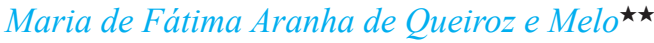 \\ Universidade Federal de São João del-Rei, São João del Rei, MG, Brasil
}

Resumo

Operamos com o conceito de fé(i)tiche, proposto por Latour, para entender o poder de influência e aglutinação de um brinquedo milenar na relação com os humanos que o têm como um objeto de alta significação em suas biografias. Neste artigo, a palavra fetiche foi problematizada para assumir uma versão composta que se traduz, ao mesmo tempo, como fato e feitiço, objeto feito e objeto encantado, passando ao largo das dicotomias entre o que é fabricação e o que é realidade. Na busca por restaurar a integração dos todos que foram cindidos pelo pensamento moderno, opta-se por estudar os fenomenos como efeitos de cadeias cujos mediadores são investigados tendo o mesmo valor enquanto operadores de efeitos. Foram privilegiadas as narrativas de pipeiros coletadas em entrevistas, assim como contribuições encontradas na literatura, realçando o poder de encantamento do papagaio de papel como objeto sagrado que protagoniza eventos e mobiliza afetos e ações.

Palavras-chaves: fé(i)tiche; brinquedo; pipa.

\section{The kite as a fé(i)tiche: bypassing of dichotomies}

\begin{abstract}
We operate with the concept of fé(i)tiche proposed by Latour to understand the power of influence and agglutination of an ancient toy in its relationship with humans that have it as an object of high significance in their biographies. In this article, the word fetish was problematized to assume a composite version which translates, at the same time, a fact and a sorcery, object made and enchanted object, bypassing the dichotomies between what is reality and what is fabrication. In the quest to restore the integration of wholes that were split by modern thought, is chosen to study phenomena as an effect of chains whose mediators are investigated with the same value as operators of effects. Narratives of kite players collected in interviews have been privileged, as well as contributions in the literature, by highlighting the power of the kite as a sacred object that is protagonist of events and mobilizes feelings and actions.
\end{abstract}

Keywords: fe(i)tiche; toy; kite.

\section{Introdução}

Buscando entender as razões para a sobrevivência do papagaio de papel ${ }^{1}$ nas práticas lúdicas de brasileiros nos meses ventosos, buscamos iluminar fenômenos eliciados por este brinquedo milenar, operando com o conceito de fé(i)tiche cunhado por Bruno Latour, uma vez que este nos oferece a possibilidade de entender os objetos como deslocadores de ações, fato que interessa a uma psicologia social que se propõe como campo de estudos sobre os efeitos produzidos pela troca de propriedades entre elementos humanos e não humanos nas conexões que estabelecem. Iniciaremos problematizando a diferença entre o fetiche e o fé(i)tiche, levantando as implicações desse entendimento para os discursos da ciência e da religião, ambos fabricações assentadas em longas cadeias de mediadores. Para a pesquisa, a busca de simetrias, entre o que é falso e verdadeiro, entre o que é fabricação e o que é realidade, constitui uma maneira de reintegrar pólos que o pensamento moderno cindiu na sua ânsia por controlar a imprevisibilidade dos fenômenos. Pelo entendimento de um mundo integrado, o brinquedo em questão, que é apontado na simbologia de mitos e lendas

\footnotetext{
^Fonte de financiamento: o artigo é uma versão adaptada de um capítulo de tese de doutorado da autora financiado com bolsa Capes.

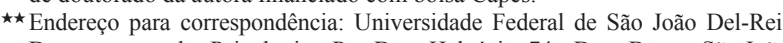
Departamento das Psicologias. Pça Dom Helvécio, 74 - Dom Bosco. São João del Rei, MG - Brasil. CEP: 36301-160.E-mail: fatimaqueiroz.ufsj@gmail.com No Dicionário da Enciclopédia Mirador (1979, p. 1272), define-se pipa como "uma espécie de papagaio de papel. O papagaio, por sua vez, é o nome comum dado às várias formas de um brinquedo de crianças que consiste numa armação leve feita de varetas e forrada com papel; destina-se a ser mantido no ar, contra o vento, por meio de um fio longo. Uma longa tira, o rabo, pendendo-lhe do vértice inferior, assegura-lhe relativa estabilidade". Apesar das várias denominações atribuídas ao brinquedo, seguiremos utilizando o termo pipa por ser o mais difundido.
}

de diversas procedências, se oferece como um fé(i)tiche, um objeto mágico outrora sagrado, que restaura um elo perdido entre o céu e a terra, entre humanos e deuses.

\section{Fé(i)tiche: ao mesmo tempo fabricação e realidade}

Os produtos da ação humana, ao longo da história, adquirem o estatuto de verdades que não passam de fabricações, por vezes tornadas maiores que seus próprios criadores. Os fenômenos da realidade em que estamos imersos têm uma história e são construções resultantes de múltiplas influências, não importa se estamos falando de fatos científicos ou de crenças religiosas. Como fabricações, não deixam de ser reais e de operar efeitos sobre nossas vidas.

Das ideias de Latour, uma delas nos será fundamental para estudar a relação dos sujeitos com a atividade lúdica, assim como o papel do brinquedo, este artefato construído pelos humanos e que hoje se constitui como um objeto valorizado nas práticas dos homens contemporâneos: a ideia de fé(i)tiche ou de fatiche. Trata-se de um termo que comporta uma composição entre as palavras fetiche e fato. Latour (2002a) chama a nossa atenção para a etimologia das palavras "feitiço", "fetiche" e "fato" como contendo a mesma raiz, ${ }^{2}$ ou seja, daquilo que é feito, fabricado. Através desta análise, o autor observa que a ideia de fetiche, como algo construído e fabricado, também

\footnotetext{
${ }^{2}$ No dicionário Aurélio de Português, encontramos o significado das palavras feitiço, fetiche e fato (FERREIRA, A. B. H., 1986, p. 614; 619; 623): Feitiço \{de feito + iço\}; 1. Adj. Artificial, factício; 2. Postiço, falso; 3. Malefício de feiticeiros; 4. Ver bruxaria; 5. Ver fetiche; 6 . Encanto, fascinação, fascínio. Fetiche; 1. Objeto animado ou inanimado, feito pelo homem ou produzido pela natureza, ao qual se atribui poder sobrenatural e se presta culto, ídolo; manipanso. Fato 1. Coisa ou ação feita; 2. Aquilo que realmente existe, que é real.
} 
aparece marcada na etimologia de palavras análogas em outras línguas como a demonstrar que o "fetiche" assume inteiramente a condição daquilo que, criado pelo homem, pode acrescentar alguma coisa, ao invés de simplesmente inverter a origem da ação, dissimulando o trabalho humano de manipulação. Segundo Latour (2002a, p. 46)

A palavra fetiche e a palavra fato possuem a mesma etimologia ambígua [...] A palavra fato parece remeter à realidade exterior, a palavra fetiche às crenças absurdas do sujeito [...] Ao juntar as duas fontes etimológicas, chamaremos de fé(i)tiche a firme certeza que permite passar da prática à ação, sem jamais acreditar na diferença entre construção e compilação, imanência e transcendência.

Ao nos determos na palavra fetiche, verificamos que ela já tem sido usada em outros domínios trazendo semelhanças e diferenças com a versão composta e utilizada atualmente por Latour. Segundo Sebeok (1988), a palavra deriva diretamente do termo português "feitiço", cunhado por marinheiros portugueses no século XV. Foi aplicado, inicialmente, na costa oeste do continente africano, aos objetos de culto que os negros carregavam junto ao próprio corpo, venerando-os por acreditarem que estes objetos, utilizados como talismãs e amuletos, tinham o poder de enfeitiçar. Em seu livro $O$ culto dos deuses fetiches, Charles de Brosses (1760, apud SEBEOK, 1988, p. 12) registra este fato e colocase como inventor do termo "fetiche" que depois será utilizado pelos antropólogos como

[...] um objeto inanimado venerado por selvagens por causa de seus poderes mágicos, supostamente inerentes, ou por ser animado por um espírito. Num sentido ainda mais amplo, fetiche chegou a referir-se a uma coisa irracionalmente reverenciada.

Trata-se de uma palavra de uso problemático que, com o tempo, abriu brechas para outras interpretações e significados em função do terreno que a absorvia. Tanto feitiço como fetiche são termos freqüentemente encontrados na literatura com o significado de "algo feito", tendo relação com as estratégias utilizadas pelo homem para controlar o mágico, o sobrenatural, outorgando a outrem a origem de sua própria ação. Segundo Sebeok (1988), tanto Charles de Brosses como Auguste Comte interpretam o fetiche como uma base para suas teorias a respeito da origem da religião. Nessas teorias, as religiões primitivas tomam coisas vivas ou coisas inanimadas para atribuir-lhes o poder de captar forças naturais: objetos ou acontecimentos são sacralizados, passando a ser adorados e reverenciados pelo seu suposto poder de funcionar de maneira positiva para influenciar e mudar as relações sociais naturais, na cura de doenças, inclusive para induzir a uma disposição erótica. Sebeok considera que foi nesta última acepção que o termo penetrou na literatura psicanalítica.

No discurso clínico da psicanálise, segundo Augé (1989), o termo fetiche foi adotado para descrever como um objeto que, aparentemente isento de significado sexual para a maioria das pessoas, pode se revestir de um determinado poder para despertar e/ou intensificar a atividade sexual. Trata-se de um fenômeno construído gradativamente na história do portador do fetiche que torna o objeto indispensável na sua atividade sexual, chegando a substituir o parceiro sexual vivo. $\mathrm{O}$ objeto do fetiche passa a ter, portanto, um valor fabricado pelo fetichista que acredita e age como se este objeto fosse mais do que realmente é, dotado de poderes sem os quais sua atividade sexual não ocorreria a contento.

O termo fetiche também foi utilizado no discurso de Marx (1983) para analisar o relacionamento das pessoas com os produtos de consumo. Quando um artigo de consumo é investido de poderes que nele não estão presentes nem lhe são inerentes, elevamos esta mercadoria ao status de fetiche, estratégia continuamente utilizada pela propaganda para estimular o consumo através da criação de necessidades secundárias. Ou seja, os produtos não são comprados apenas pelo seu valor de uso, mas por todos os pseudopoderes que carregam. Neste caso, percebemos uma dupla fabricação: a do produto em si e a da necessidade de consumi-lo, artificialmente criada pela fetichização do objeto.

Tanto na psicanálise como na teoria marxista, o fetiche aparece como um objeto, fabricado ou construído, investido de poder que, por um processo de ritualização, passa a exercer um certo fascínio sobre os sujeitos que fazem dele uma ferramenta para o que acreditam ser uma ampliação de suas possibilidades relacionais. Nos dois casos, o poder dos objetos é suposto, estando a serviço da ilusão. A palavra fetiche é utilizada em seu sentido negativo, como um movimento de submissão ao objeto que, ritualizado, esvazia a ação do sujeito: o objeto-fetiche comanda a ação, enredando o homem em comportamentos estereotipados sobre os quais ele não tem mais domínio.

Apesar de comungar com a ideia de fabricação humana, a palavra fetiche, em Latour (2001, 2002a), passa a associar-se a um outro registro, mais positivo, abandonando o cunho patologizante da psicanálise, ao mesmo tempo em que introduz simetria no processo de atribuição de sentidos aos objetos da realidade. Tornase possível ultrapassar a dicotomia entre fato feito ou fabricado versus fato encantado com o efeito mágico que ele produz. Surge uma fusão de ambos os significados com o termo fé(i)tiche, sem, entretanto, incorrermos em uma contradição.

Desta forma, poderíamos alocar na categoria de fé(i)tiche desde os amuletos utilizados pelos negros na Costa do Marfim, aos ídolos religiosos venerados pelos portugueses - para falar das religiões como uma necessidade humana de criar poder e força em algo para além do próprio homem - assim como poderíamos falar do discurso científico em que fatos são engenhosamente produzidos, gerando conseqüências que nos afetam a todos, adquirindo uma enorme força na maneira como nos conduzimos em nossas vidas, em nossa relação com a natureza e com outras entidades (humanas e não humanas). Fetichistas e antifetichistas são postos em pé de igualdade, simetricamente colocados numa forma de ver as coisas a que Latour (2002a) chamou de Antropologia Simétrica.

Fractal, Rev. Psicol., v. 28 - n. 3, p. 341-350, 2016 
Por que não confessar simplesmente que não há nem fetichismo nem antifetichismo, e reconhecer a eficácia singular desses "deslocadores de ação" aos quais nossas vidas estão intimamente ligadas? (LATOUR, 2002a, p. 31).

Não há mais razão para abdicar da palavra "fetiche" como da palavra "fato", sob o pretexto de que os modernos teriam acreditado na crença e quiseram desacreditar os fatos para ater-se aos fetiches (LATOUR, 2002a, p. 46).

\section{Buscando simetrias}

Diz Latour (2002a) que a separação entre o objeto feito como fato, assentado em sólidas causas objetivas, e o fetiche como objeto encantado, projeção de uma miscelânea de crenças sem importância, é obra de um tipo de pensamento que se estabeleceu com a modernidade. Os pensadores modernos produziram um processo de separação que resultou na clivagem de várias instâncias, na forma como os sujeitos passaram a entender a realidade: fatos $\mathrm{x}$ fetiches, crença ingênua $\mathrm{x}$ ciência, sujeito $\mathrm{x}$ objeto, natureza $\mathrm{x}$ cultura, teoria $\mathrm{x}$ prática, coisa $\mathrm{x}$ representação, interioridade $\mathrm{x}$ exterioridade, ciências da natureza $\mathrm{x}$ ciências humanas.

Ou bem [o cientista] construiu socialmente seus fatos e acrescenta ao repertório do mundo apenas suas fantasias, preconceitos, hábitos e memória, ou bem os fatos são reais, mas então ele não os fabricou em seu laboratório. Essa contradição parece tão fundamental que ocupa, ininterruptamente, há três séculos, a filosofia das ciências (LATOUR, 2002, p. 37)

O que Latour propõe é fugir da escolha cominatória, é contornar essas clivagens, abandonando a dureza das categorias cartesianas, em prol de um tipo de pensamento que não seja dicotômico, sempre na busca por restaurar a integração dos "todos" que foram cindidos pelo pensamento moderno.

Fatos e valores emergem igualmente das redes em que o trabalho de fabricação se processa ativamente misturando elementos muito heterogêneos. Ciência e religião possuem discursos próprios cuja eficácia está atrelada a maneiras particulares e distintas de atuar sobre a realidade, mas ambos se nutrem de fabricações humanas e operam como deslocadores de ação. Latour (2002b) entende os discursos da religião e da ciência como situados em domínios diferentes, mas reconhece que tanto um como outro fazem uso de cadeias de mediadores para provocar seus efeitos. A ciência, através de seus procedimentos, cálculos e modelos, tenta produzir informação precisa e confiável, enquanto a religião pretende reafirmar, através da iconografia cristã, o movimento que renova a fé diante dos mistérios, através das mensagens proferidas. No caso da ciência, o discurso quer informar com objetividade. No caso da religião, tal como na linguagem do amor, busca-se o enlevo, a transformação pela fé.

Tanto o discurso religioso como o discurso científico levam a coisas que não podem ser diretamente observadas, valendo-se de cadeias de mediadores que conduzem nossa observação para direções que são próprias a cada um dos campos. A cadeia de mediadores da ciência leva ao que é invisível porque seu objeto está muito distante e não se alcança pela intuição, mas pelo incansável trabalho de pesquisar, recortar, traduzir a realidade em representações confiáveis. A cadeia de mediadores da religião também conduz ao invisível, sendo o seu objeto inalcançável porque ele é simplesmente difícil de renovar: a fé em seus mistérios. Ambos, entretanto, se colocam a tarefa de encontrar uma "verdade"- uma fabricação -, buscando a continuidade do fluxo na cascata de mediações, sempre um passo além.

$\mathrm{O}$ que nos interessa nestes argumentos de Latour (2002a, 2002b) é a possibilidade de entender a inserção do brinquedo em um tipo de discurso que, para nós, tanto pode estar na cadeia de mediadores utilizados pelo discurso científico - quando encerra as ações de descoberta e invenção como expressões do pensamento criativo - como pode fazer parte de uma cadeia de mediadores da comunicação que transporta e que transforma - como no discurso da religião. Tal como nos discursos da ciência e da religião, o lúdico se estrutura sobre o fluxo de uma cascata de mediadores, pois está constantemente representando, significando e ressignificando. $\mathrm{O}$ brinquedo como objeto não se esgota em sua concretude e "deixa falar", pois permite um fluxo constante de sentidos que traz o passado ao presente e projeta o presente no futuro. ${ }^{3} \mathrm{O}$ brinquedo teria, ao mesmo tempo, um valor funcional e um valor simbólico, ou seja, tem um uso em potencial porque é simbólico tem uma significação social; e tem um valor simbólico, porque se presta a vários usos (BROUGÈRE, 2000).

Desta forma, o objeto lúdico pode ser compreendido através dos dois tipos de registro: o que informa e o que transforma. No primeiro tipo, o brinquedo conteria sua própria história, a ser desvelada, descoberta em sua condição de artefato que mobilizou e cristalizou em materiais as ações lúdicas praticadas, inserido em um contexto sócio-histórico-cultural determinado, abrindo um campo de descoberta e invenção pelo ato criativo. No segundo registro - como comunicação que transforma - o brinquedo constitui-se numa linguagem que re-inventa, que subverte, que significa e re-significa, re-estabelecendo uma via mestiça (SERRES, 1993) ou híbrida (LATOUR, 2001) que dá aos sujeitos a possibilidade de expressão "des-enformada", à fala que transporta e que arrebata.

\section{Pelo entendimento de um mundo integrado}

A palavra fé(i)tiche ou fatiche, adotada por Latour (2002a) para expressar ao mesmo tempo fato e feitiço, objeto feito e objeto encantado, traduz bem a ideia de que categorias dicotômicas e freqüentemente colocadas como antagônicas podem voltar a um estado de entendimento integrado e serem traduzidas à luz de uma restauração que as coloca no estatuto de tudo o que é fabricação humana. Restaurados os objetos dessa fabricação, a dupla noção de saber e de crença poderia ser abandonada, permitindo aos "atores por eles mesmos", enunciarem

\footnotetext{
${ }^{3} \mathrm{~A}$ ação de brincar ocorre sob a mesma lógica: uma menina, quando materna sua boneca, traz do passado a referência que a inspira, ao mesmo tempo em que se projeta no futuro a partir de um repertório das ações que um dia será capaz de realizar em toda a sua plenitude.
} 
seus próprios discursos, livres da censura de rótulos arbitrariamente criados e impostos pelas categorias científicas psicologizantes e normatizadoras, habilmente guardadas em escaninhos disciplinares.

Os antifetichistas se fundam sempre numa acusação de que os outros é que são os crentes e que, incrédulos, eles estão imunes à crença ou à manipulação. Para ultrapassar a noção de crença como uma forma menos valorizada de apreender a realidade, o autor propõe que lancemos o olhar aos cientistas, em sua prática de laboratório, ou aos adeptos dos cultos em seus ritos, pois eles certamente são capazes de entender essa natureza ambígua de fatos e fetiches. As imagens que criamos como objetos de culto, os nossos ídolos, seja no campo da religião, seja no campo da ciência, são fabricações - fé(i)tiches - de que nos valemos para entender o mundo e a nós mesmos.

No laboratório, os fatos são fabricados por uma longa e complexa negociação, por uma cadeia de articulações que os vão produzindo. Trata-se de um fenômeno que depende das qualidades do humano, assim como das qualidades dos não humanos envolvidos; há uma parte controlada e uma outra parte inesperada e insuspeitada que surge na esteira das surpresas que nossa própria fabricação nos traz. Nem por isso os fatos são enfraquecidos: nem somos completamente autores dos fatos, nem os fatos o são deles próprios. Há uma complexidade nos fatos que, longe de fragilizá-los, enriquece a sua fabricação.

Com o fé(i)tiche acontece a mesma coisa, pois ele é igualmente fabricado, sendo que o reconhecimento dessa fabricação também não pode constituir um elemento para o seu enfraquecimento. Pelo contrário, a sua fabricação o torna "mais forte, muito mais reflexivo, ricamente investido numa prática coletiva [...]" (LATOUR, 2001, p. 313).

Com a noção de factiche ou fé(i)tiche, Latour (2001, 2002a) sugere um movimento completamente diferente: é pelo fato de ser construído que ele é tão real; é por ter tantas ligações que ele ganha autonomia. A mediação humana, restaurada tanto no fato como na crença, recoloca o estatuto de mistura entre fabricação e realidade. Fatos e fetiches são, ao mesmo tempo, ambos: fabricação e realidade. Passa-se ao largo da divisão que coloca fatos como reais e crenças como ilusórias. Fatos e crenças são fabricados e reais na medida em que operam deslocamentos de ação, que produzem efeitos, sejam eles bons ou maus.

A divisão operada pelo pensamento moderno entre fato e crença reforça uma atitude assimétrica frente a outras culturas, negando a necessidade de fabricarmos a nós e ao mundo para agir e argumentar. A noção de crença se tornou um fardo, segundo o autor, pois, além das religiões, a própria ciência foi colocada em questão. $\mathrm{Na}$ ânsia antifetichista de desmontar as crenças e condenar à ingenuidade os seus portadores, foram deixadas de lado as bases do que é ser humano. Aceitando os nossos fé(i)tiches, colocando-nos diante das fabricações que empreendemos em parceria com outras entidades, temos a chance de avaliá-las pelos efeitos que elas produzem.
Cada produto das associações que fazem os humanos com os elementos que com eles co-existem passa a implicar responsabilidade e compromisso com a sua existência.

\section{Metodologia}

As ideias de Latour são instigantes para pensar os mais diversos fenômenos que estudamos. Com imersão num campo-tema que nomeamos como "ludicidade e sociotecnologia", a escolha da pipa e da rede que a sustenta ainda hoje entre as brincadeiras mais populares de que se tem notícia se deu como um movimento natural. Num breve movimento de mapear suas conexões, encontramos a pipa relacionada com várias histórias: com a história das civilizações, desde a sua invenção em tempos distantes; com a proto-história da aviação e das técnicas ligadas ao trabalho dos engenheiros (a matemática e a física); com a história dos usos e costumes dos povos; com a história das ideias e crenças religiosas. Ao se deslocar por essas redes, a pipa passou por um movimento de tradução que foi lhe conferindo diferentes versões em função do papel desempenhado em cada um dos coletivos que pôde compor. Tornou-se para nós um objeto emblemático e altamente imantado pelas projeções e delegações que lhe fazemos e pelas possibilidades de nos fazer operar com conceitos que encontramos na obra de Latour. Além disso, a pipa como um fenômeno da vida cotidiana nos ajuda a entender uma série de questões relacionadas às aprendizagens - das destrezas, da ocupação do espaço, das regras que regulam as interações, do controle das emoções, da arregimentação de aliados humanos e não humanos, da construção de uma postura diante da natureza e seus ciclos. Como parte do trabalho, através de relatos coletados em entrevistas e registros na literatura, pudemos flagrar o envolvimento de algumas pessoas com o brinquedo, demonstrando a sua potência como protagonista de eventos e operador de efeitos. Os sujeitos que buscamos para entrevistar, os nossos narradores privilegiados, foram pessoas que encontramos por indicação daqueles que travaram contato com nossas intenções de pesquisa. O primeiro acesso se deu através da viúva de um pipeiro e construtor de pipas que desejou preservar o acervo de objetos voadores construídos pelo marido, doando-o para nossa Brinquedoteca Universitária. Através das informações prestadas neste contato, nos foi possível tecer uma rede de pessoas que iam indicando nomes de antigos parceiros de brincadeira, conhecidos, parentes e até familiares de figuras lendárias na cidade por seu trato com o brinquedo. De alguma forma, todos eles, em suas biografias, ofereciam uma narrativa muito singular sobre sua relação com a pipa. Contamos com um grupo de narradores com idades entre 19 e 70 anos que incluiu um estudante, dois comerciantes, um funcionário público, uma carnavalesca, um carteiro, um ferroviário aposentado, uma enfermeira e uma professora que tinham a pipa como objeto de alta significação em suas vidas. As entrevistas foram transcritas e foi feita a devolução de uma cópia de cada uma aos respectivos entrevistados para que pudessem fazer os reparos (inclusões e exclusões que considerassem adequadas), tornando-os, desta forma, participantes e autores de seus 
textos. O material coletado foi editado e, posteriormente, foram classificados os fragmentos que aludiam à pipa nos diferentes papeis por ela desempenhados. Para este artigo, foram selecionados os fragmentos que nos ajudam a entender a pipa como um fé(i)tiche. Excertos de livros com o mesmo teor foram mesclados aos depoimentos dos nossos entrevistados.

Os festivais que tiveram a pipa como um elemento aglutinador foram acompanhados durante dois anos em três cidades de Minas Gerais, tendo a Companhia Energética de Minas Gerais (CEMIG) como parceira interessada na ampla divulgação da brincadeira associada às regras de segurança para a prevenção de acidentes. Foram pesquisados registros sobre a organização dos festivais a partir de documentos disponibilizados na sede da CEMIG, em Belo Horizonte, assim como foram feitas observações em diário de campo durante a nossa presença aos eventos.

\section{A pipa como objeto sagrado: singela ligação entre o céu e a terra}

Os objetos queusamos surgem de desejos enecessidades reais e são causa de inúmeros comportamentos. A mesma argumentação poderá ser usada para os objetos que se prestam aos nossos cultos. É sabido que esses objetos a cujo culto nos dedicamos, explicitamente ou implicitamente, guardam histórias que justificam a sua simbologia. Alguns outros fizeram o caminho contrário e, hoje, dessacralizados, passam a um outro estatuto de utilização, muitos deles tornados brinquedos. ${ }^{4}$

Tanto Benjamin (1984) como Ariès (1981) colocam-nos diante da ideia de que os brinquedos, primitivamente, eram objetos utilizados nos afazeres e rituais do mundo adulto que, graças à imaginação infantil, foram resgatados como peças para realizar as várias experimentações das realidades físicas e sociais que as crianças costumam empreender.

Com o tempo, a brincadeira se libertou de seu simbolismo religioso e perdeu seu caráter comunitário, tornando-se ao mesmo tempo profana e individual. Nesse processo, ela foi cada vez mais reservada às crianças, cujo repertório de brincadeiras surge então como um repositório de manifestações coletivas abandonadas pela sociedade dos adultos e dessacralizada (ARIÈS, 1981, p. 89).

Embora nem todos os brinquedos infantis sejam heranças do mundo adulto, pois pensando assim estaríamos negando a capacidade inventiva das crianças para criar seus próprios objetos lúdicos, não podemos negar o fato de que alguns deles derivam dos ritos e objetos sacralizados que sobreviveram com novas traduções no imaginário infantil, como parece ser o caso do papagaio de papel ou pipa. Além disso, ambos os autores mostram que o brinquedo, tal como o entendemos hoje, em sua origem relativamente recente, surge reforçando e sendo reforçado com a "invenção" da categoria de infância, gestada ao longo

\footnotetext{
${ }^{4}$ Mesmo na condição de brinquedos, estes objetos funcionariam como fe(i)tiches pois continuariam a operar como deslocadores de ações, ao mesmo tempo como fatos reais e fatos encantados, não estando, portanto, tão dessacralizados.
}

destes últimos séculos. ${ }^{5}$ É, predominantemente, ${ }^{6}$ na relação com a criança que o brinquedo aparece com toda a sua força de realidade e de encantamento, operando efeitos inesperados. Pessoas de idades muito variadas compartilham a paixão pelo papagaio.

[...] O meu neto aprendeu no grupo mesmo. Acredita? Ele é doido pra me pedir trocado pra comprar papel. [...] Perguntei o que que era aquilo ali. Ele disse que estava pondo cara no papagaio. Depois ele cortou uma meia-lua, deu uns furinhos no meio, colou aquilo e parecia uma boca rindo com os dentes. Ficou interessante. Depois ele foi soltar a pipa. (Trecho da entrevista com B., ferroviário aposentado)

$\mathrm{O}$ entrevistado diz que não teve participação no aprendizado da pipa que fez o neto, mas assumiu a sua participação no aprendizado feito por outros meninos e pela avó que moravam na roça. Três gerações, nestes fragmentos de entrevista, aparecem para mostrar que o trato com este brinquedo não tem idade para acontecer.

[...] Mas quem aprendeu em primeiro lugar e soltou pipa foi a minha avó. Ela achou tão interessante aquilo lá que falou: "Mas como é que você faz?" Eu expliquei como é que fazia [...] Ela fez e começou a pegar o jeito. Eu fiquei ensinando uns truques pra ela [...] Ela gostou tanto que, quando a minha mãe chegou lá na janela da casinha pra chamar a vó, ela disse: "Não posso ir agora. Tô soltando papagaio. Você devia vir também!" (Fragmento da entrevista com B. ferroviário aposentado)

Outros brinquedos também operam esse efeito de encantamento, mas no caso da pipa, Rios (2003) faz uma série de considerações que nos permitem pensar este objeto como um instrumento dedicado aos rituais religiosos. Ao voltar o olhar para o céu, o homem sempre o teve como motivo de atração e desafio. A necessidade de elucidar os mistérios da vida tem impelido os homens à fabricação de deuses e doutrinas religiosas para aplacar um sentimento de pequenez diante de um mundo extraordinariamente grande, incompreensível e, muitas vezes, fora de seu controle. Por esta razão, quase todas as mitologias retomam formas para diminuir ou eliminar a distância que separa céu e terra, deuses e humanos, remetendo a alguns dos simbolismos que nos possibilitam pensar a pipa como um objeto sagrado de culto em culturas arcaicas. ${ }^{7}$ Verificamos que a pipa, para além de seu valor lúdico, encerra a capacidade de ser um deslocador de ação, um operador de realidade do qual ainda se valem todos aqueles que lhe atribuem um valor de encantamento cujas raízes podem ser verificadas em tempos remotos. Observamos, também, que a tentativa de ascender aos céus é uma constante em todas as religiões a partir da utilização dos mais diversos artifícios, sendo a pipa apenas um deles.

\footnotetext{
${ }^{5} \mathrm{O}$ reconhecimento da infância, enquanto uma etapa do desenvolvimento do ciclo vital, aparece como resultante de uma longa cadeia de fatos que têm relação com as mudanças ocorridas em diversos domínios, todos estes estabelecendo redes que permitiram o reconhecimento do brinquedo como um objeto de valor para a sociedade contemporânea.

${ }^{6}$ Mas não exclusivamente, pois se verifica que alguns objetos mantêm sua força mobilizadora em outras idades da vida humana.

${ }^{7}$ Utilizaremos o termo arcaico no sentido de ancestral e, de maneira nenhuma, o entendemos com a conotação de atrasado.
} 
$\mathrm{Na}$ mitologia grega, por exemplo, encontramos a imagem da "corda de ouro" com a qual Zeus podia puxar para si todas as coisas e manter os laços que seguram a unidade indestrutível do universo, assim como as ligações entre o homem e os poderes superiores. $\mathrm{Na}$ Austrália, os medicine- $m e n^{8}$ também falam que, ligado ao seu corpo, há um cordão milagroso, uma corda mágica com a qual afirmam subir ao céu e têm a chance de realizar proezas maravilhosas. Verifica-se que há, com relação a essa corda mágica, uma mesma articulação de elementos, na Austrália, na Índia e no folclore medieval europeu: ciência, magia, corda mágica, ascensão, voo celeste. Percebem-se, tanto na especulação filosófica hindu como entre os pensadores gregos, as imagens arcaicas da corda, do fio e da tecedura como ponto de partida para as teorias cosmológicas e para a descrição da condição humana (ELIADE, 1991).

[...] A gente descobre que, no fundo, acaba fazendo parte daquele bambu e daquele papel que ficam lá em cima voando. A sensação de soltar pipa é uma coisa que a gente sente, mas a gente não consegue explicar. Por quê? Como é possivel estar num extremo da linha e, do outro lado, aquela pipa lá no alto? Eu sentia inveja! Por que a gente não podia trocar de extremo? Eu queria voar, mas estava preso. É uma sensação de leveza e ao mesmo tempo uma sensação de impotência porque a gente fica no chão segurando uma coisa que está voando. É uma liberdade provisória porque, se o tempo acaba, se o vento acaba, a pipa cai. É uma coisa gostosa de sentir e gostosa de viver. (Trecho da entrevista com P.A., funcionário público)

Quanto ao "voo", há um vasto conjunto de mitos, ritos e lendas, segundo Eliade (1957). Tal como a imagem da corda, o voo mágico é solidário de um grupo de mitos relativos à origem dos humanos numa época em que céu e terra eram um só. O simbolismo do voo está próximo do simbolismo das asas: ascensão, abolição do peso, compreensão das coisas secretas, das verdades profundas, dos poderes da inteligência. Constata-se então que a imagem do voo e seus simbolismos paralelos têm a função de traduzir um rompimento das amarras com a experiência cotidiana a partir de um duplo objetivo - de transcendência e liberdade - "uma mutação ontológica do ser humano" (ELIADE, 1957, p. 95), algo que implica numa mudança de nível, na passagem de um modo de ser a um outro.

Outra ideia que vem corroborar a importância do simbolismo da corda, do voo mágico e da ascensão, no estudo da pipa, é a de que estas imagens exprimem matizes novos traduzidos em contextos diferentes. Segundo Eliade (1991, p. 203), "as imagens ajudam e até forçam o homem a pensar, a tornar suas ideias precisas, a descobrir continuamente significações novas, a aprofundá-las e articulá-las". Para o autor, quando estudamos os símbolos, não se trata de fazer um trabalho de redução, mas de integração, buscando descobrir o que permanece constante em fatos aparentemente heterogêneos, procurando os vários fios que os ligam, assim como as múltiplas versões que os vão revestindo de novas significações, em contextos particulares.

${ }^{8} \mathrm{O}$ que teria uma tradução equivalente a "curandeiros".
Em épocas remotas destituídas de avanços tecnológicos, em que os ritos e magias eram as fabricações possíveis aos homens, o papagaio, em sua simplicidade construída de bambu, papel, fio ou barbante foi um artefato mágico através do qual um reles mortal subia ao céu levado pelos ventos. Conforme Rios (2003), é provável que o homem tenha efetuado um movimento para transferir aos objetos voadores alguns de seus anseios de transcendência. Verifica-se que, em várias épocas da história, são utilizados objetos dotados de força mágica que auxiliam o homem a realizar o movimento ascensional do voo: cavalos alados, pássaros, vassouras, cordas e... pipas! Em vários países, diz Eliade (1957, p. 11), "o ato de empinar pipa se faz acompanhar de rituais que marcam sua função mágica”. Para este autor, não está em questão se estas experiências são verdadeiras ou se resultam de sonhos ou fantasias, mas a força mobilizadora da experiência imaginária como constitutiva do ser humano, paralela à experiência diurna das atividades práticas, assim como seus efeitos.

[...] Eu sempre tive vontade de ser uma pipa. Bem leve, sem levar nas costas nada que pese (o que é pesado leva a gente pra baixo...). Papel de seda, taquara fina que enverga, mas não quebra, linha forte, um pouquinho de cola e, pronto! Lá está a pipa pronta para voar... As cores e as formas (que são tantas!) a gente escolhe aquelas que o coração está pedindo. Pipa, pra ser boa, tem que se parecer com os nossos desejos. (E eu penso que as pessoas também, para serem boas, têm de ter uma pipa solta dentro delas...). Não é preciso vento forte. Uma brisa mansinha deve chegar para levá-las até lá em cima, perto das nuvens. É por isso que elas têm de ser bem leves. O vento chega, as folhas das árvores tremem, e lá vão elas subindo, pra dentro do vazio do céu... (ALVES, R., 1986, p. 6-9).

A ideia de fé(i)tiche postulada por Latour (2001, 2002a) traz-nos a possibilidade de percebermos humanos e não humanos nessas trocas de propriedades em que, ao delegarmos papéis às nossas fabricações, ao nelas nos projetarmos e por elas sermos arrebatados, conferimoslhes a capacidade de operar mudanças enquanto na condição de deslocadores de ações. É aí que reside a força dos discursos religiosos que fazem uso, como no discurso das ciências, de cadeias de imagens que se articulam na tentativa de dar consistência e concretude às "visões do espírito". 9

Mello (1983) informa que as pipas ou "papagaios", como são chamadas no Amazonas, já apareciam em práticas religiosas malaias, há mais de três mil anos quando, em cerimônias secretas, centenas de pipas feitas de folhas de palmeira serviam de oferendas para apaziguar os deuses que comandavam os ventos, na intenção de conter a destrutividade dos tufões que varriam as ilhas. Nesta região, as pipas também desempenhavam um papel vital para a indústria da pesca, à semelhança

\footnotetext{
${ }^{9}$ Em texto intitulado "Visões do espírito: uma introdução à antropologia das ciências e das técnicas", Latour (1985) chama a atenção para a necessidade que têm os humanos de recorrer às imagens para melhor explicar (ou traduzir) as suas fabricações. Seriam as imagens artifícios de entendimento e registro da realidade dos quais se valem os humanos para construir as longas cadeias de mediadores tanto no discurso científico, como no discurso religioso (LATOUR, 2002a).
}

Fractal, Rev. Psicol., v. 28 - n. 3, p. 341-350, 2016 
do que nos relata Mello (1983) sobre a pipa pesqueira no litoral de Santa Catarina, evidenciando o caráter sociotécnico ${ }^{10}$ do objeto.

No folclore da Polinésia, conta-se uma lenda sobre a disputa entre dois deuses do vento, os irmãos Range e Tane, que utilizaram artefatos voadores para medir a sua força. Tane teve a cauda de sua pipa presa e enroscada aos galhos de uma árvore o que resultou em sua derrota. Esta lenda, até hoje, é revivida pelo povo da Polinésia: durante a batalha pela supremacia dos ares, a pipa que voa mais alto é tida como possuída pelo espírito vitorioso de Range (KENT, 1997).

Os chineses soltavam pipas, havia pelos menos 200 anos antes de Cristo: como oferendas aos deuses, como forma de intimidar o inimigo, ou como meio de atrair magicamente condições de bem viver. Até hoje, no Oriente, encontramos rituais em torno do voo da pipa que continua carregando ilustrações de motivos religiosos e místicos, como atrativos da felicidade e da sorte, nas ocasiões em que são celebrados nascimentos, comemoradas vitórias ou como objeto dos rituais de fertilidade (VOCE, 2002).

Conforme Mello (1983), na China antiga, o papagaio era o principal elemento nas cerimônias de celebração do sétimo aniversário do primogênito de cada família. Feito de palha, era elevado pelo patriarca que o deixava subir até que a linha findasse, momento em que o soltava, deixando voar sozinho o pássaro mágico que com ele levava todo o mau agouro que pudesse comprometer a vida da criança. A esta cerimônia, os chineses dão o nome de "Levar embora o Demônio".

Dentro dos mesmos moldes, no dia 5 de maio de cada ano, em cada lar japonês onde tenha nascido um menino, realiza-se uma celebração denominada "Festival do Menino". Nesta ocasião, a família faz voar um objeto alado em forma de carpa, acompanhado de pipas magnificamente pintadas à mão. Esta prática encontra similares na Coréia, lugar onde se costuma fazer, nas pipas, a inscrição da data de aniversário de toda criança do sexo masculino que nasce (KENT, 1997).

O simbolismo religioso também parece estar presente na palavra francesa que designa a pipa. A palavra cerfvolant, que nomeia popularmente o lucanus, ${ }^{11}$ tem uma tradução literal - "cervo voador" - que pareceria absurda. Entretanto, assinala Rios (2003), verifica-se que o cervo, em tempos pré-históricos, tinha um simbolismo religioso ligado à criação contínua e recriação mística, devido ao fato de realizar, de tempos em tempos, uma renovação de seus chifres. Atribuir à pipa a imagem de um cervo voador equivaleria ao movimento de sacralização de um objeto dotado de uma função ritualística análoga: de elevação, de criação, de contato com o sagrado.

\footnotetext{
${ }^{10} \mathrm{O}$ adjetivo sociotécnico aparece para representar um híbrido dessa relação entre humanos e não humanos, reintegrado pólos que comumente aparecem como opostos (LATOUR, 2001)

${ }^{11}$ Nome de um inseto dotado de pequenas antenas a semelhança de chifres. Lucanista, tradução de cervolantista, é uma palavra derivada de lucanus designa, na França, o equivalente ao que chamamos de pipeiro.
}

Mas qual a relação entre a pipa dos rituais descritos e as pipas que protagonizam os eventos que presenciamos? Entendemos que estas conexões só se tornam compreensíveis se utilizarmos a lógica de um tempo e de um espaço dobrados, ideia que nos remete a um pensamento que é topológico, não mais euclidiano. Diz Serres (1993), que a topologia é o ramo da matemática que trabalha com as proximidades e os rasgos, enquanto a geometria trabalha com as distancias bem definidas e estáveis. Como estamos trabalhando com a lógica dos atores-redes, tentamos operar aproximações e efetuar passagens, o que justifica as comparações inesperadas entre espaços e tempos não mais lineares. Não estamos mais com a preocupação de mensurar fenômenos, mas de arriscar o estabelecimento de elos entre eles. Muitos milhares de quilômetros separam Minas Gerais da China, 4500 anos nos separam da época em que a primeira pipa se elevou nos céus, mas esta funciona aqui como o objeto presente em tempos e espaços que estariam muito distantes se utilizássemos uma linha reta, mas passíveis de estarem ligados se pensarmos num espaço e num tempo dobrados.

Os festivais de pipas acontecem em variados lugares, além daqueles que mencionamos. São poucos, mas expressivos, os sites que podemos acessar no Brasil com a temática das pipas se comparados ao número de sites internacionais abordando o assunto, mas estes já nos dão uma ideia da mobilização que podemos encontrar em outros países com relação aos eventos em torno das pipas, ${ }^{12}$ sejam festivais, revoadas ou projetos pedagógicos.

\section{A pipa protagonizando eventos: os festivais em Minas Gerais}

Alguns eventos protagonizados pela pipa são uma mostra da capacidade deste brinquedo para operar efeitos de encantamento e aglutinação. Um desses episódios foi o chamado "Festival do Papagaio", que tem lugar na cidade de Belo Horizonte, promovido pela CEMIG que tem realizado um trabalho em torno da cultura do papagaio, ${ }^{13}$ ao invés de se contrapor a ela. Esta ação da CEMIG tem o objetivo de diminuir a porcentagem de acidentes que têm como causa a não atenção às medidas de segurança durante a brincadeira de pipa. Verificou-se que a brincadeira de pipa promovia tal envolvimento das pessoas, no momento em que a praticavam, que estas se descuidavam das normas de segurança necessárias à prevenção de acidentes. Foi desta forma que a CEMIG constatou que o maior índice de acidentes com a rede elétrica tinha como causa, em alguns períodos do ano, a brincadeira com papagaios: pipas enroscadas na rede elétrica, atropelamentos, quedas de lajes, quedas em buracos fundos e motoqueiros cortados com o cerol das linhas foram alguns dos acidentes mais comuns

\footnotetext{
${ }^{2}$ Para saber mais sobre pipas no Brasil, consultar Equipe Silvio Voce, equipe do engenheiro aeronáutico Silvio Voce; Ken Yamazato, engenheiro mecânico e de segurança do trabalho; Portal das Pipas; Pipas Kites \& Cia.

${ }^{13}$ Papagaio tem sido o termo utilizado em Belo Horizonte, apesar de pipa ser mais corrente na região de Minas que estamos investigando. Papagaio e pipa, entre outros termos, designam o nosso objeto em questão. Apesar de sofrer algumas modificações no seu formato e, por conta destas, ter nomes variados em cada região, o brinquedo é reconhecido como o mesmo objeto. Durante todo o trabalho, usamos de forma indistinta uma ou outra terminologia.
} 
verificados durante a temporada de pipas. Ao invés de promover campanhas cujo objetivo seria a extinção do brinquedo e da brincadeira, como já havia sido tentado inocuamente, em outras épocas e lugares, ${ }^{14}$ a CEMIG fez a opção de ter a pipa como uma aliada nas campanhas educativas sobre as normas de segurança envolvendo as redes de distribuição de energia, associando-se ainda a uma preocupação com a preservação ambiental. $\mathrm{O}$ referido Festival do Papagaio tem acontecido desde 1980, mobilizando cerca de vinte mil pessoas que chegam ao Parque das Mangabeiras, área de proteção ambiental, movidas pelo desejo de empinar papagaios, encontrar com velhos amigos, ensinar e aprender técnicas de empinagem, passar adiante a amigos, filhos, netos, sobrinhos, uma aprendizagem que provavelmente se teceu de maneira informal, por pura diversão. Ao elevar o olhar para cima, o que se via era comparável a um céu pontilhado de estrelas multicoloridas que se moviam sem cessar numa cadência quase musical. Em baixo, linhas e carretéis se confundiam entre os mais variados grupos.

Famílias inteiras e grupos de pipeiros organizados costumam comparecer a este evento de maneira tão fiel que a CEMIG nunca precisou de grande divulgação para que o festival acontecesse ao longo desses anos, sempre no primeiro domingo do mês de agosto, de forma semelhante a outros "festivais do papagaio" 15 de que temos notícias. O Festival do Papagaio de Belo Horizonte conta com uma estrutura simples, eficiente e bem montada, por parte da CEMIG, repetindo uma receita que faz sucesso a cada ano: o concurso ${ }^{16}$ conta com grupos de street dance, funk, banda de música, uma grande tenda colorida estrategicamente colocada para fazer fachada à área de soltar as pipas, um palhaço devoto ao festival que faz a sua animação em grande estilo, desde o seu início, juízes, comissão organizadora, segurança oferecida pela polícia e milhares de pessoas com suas pipas. É um dia para o encontro motivado pela pipa cuja força aglutinadora nem sempre pode ser encontrada em outros objetos. É possível flagrar pipeiros mais velhos com seus antigos carretéis de madeira, mãe e filha com pipa em forma de "menina superpoderosa", muitas duplas de pais e filhos, por vezes acompanhados de cachorros, famílias reunidas que se divertem num domingo de sol e céu claro. Os concorrentes disputavam a prêmios, nas categorias beleza e originalidade, tentando fazer jus a um tema, considerado difícil por uma das organizadoras, que era "Com segurança não se brinca". ${ }^{17}$ Nestes moldes, ou em formato semelhante, temos notícia de que festivais ou torneios em torno deste brinquedo

\footnotetext{
${ }^{14}$ Thiago de Mello (1983, p. 41) comenta, em seu livro, a caça às pipas empreendida por um chefe de polícia em Manaus na época de sua adolescência que, segundo o poeta, "era uma pessoa grande que, em menino, tinha sido ruim de papagaio, ruim de bola e, pior de tudo, ruim de infância". No Rio de Janeiro, em 1958, uma campanha parecida foi deflagrada pela Light Serviços de Eletricidade S. A. (Light SESA), através da imprensa, despertando a reação negativa de outro poeta, Carlos Drummond de Andrade.

${ }^{15}$ Ver na internet, sob a expressão chave "festivais de pipas no mundo", a quantidade de eventos envolvendo as pipas que acontecem com regularidade em vários pontos do planeta.

${ }^{16}$ As pipas candidatas não podem ser de plástico, nem seus fios podem ter cerol, pois é contra as normas de segurança e, portanto, contra o regulamento.

17 "No ano passado, o tema Água doce foi mais fácil de contemplar e as pipas ficaram mais bonitas", diz uma das coordenadoras do evento de 2004.
}

também acontecem em outros lugares do Brasil. Tratase de um fenômeno verificável em muitas partes do mundo que tem sua tradução local em termos das formas construtivas, das designações atribuídas ao objeto, das regras utilizadas durante a brincadeira, do vocabulário específico de cada grupo. O fato a ressaltar é que o papagaio - ou a pipa - proporciona uma atividade lúdica que afeta uma quantidade surpreendente de pessoas, ${ }^{18}$ independentemente da idade, da condição social e da nacionalidade. Foi, provavelmente, o momento mais intenso em que tivemos clareza das proporções de público que a pipa era capaz de arregimentar. Comparecemos a outros festivais patrocinados pela CEMIG executados de forma mais doméstica, mobilizando assim, públicos menos expressivos pela sua fraca divulgação e sem a tradição construída pelo primeiro, ao longo destes anos.

\section{A pipa operando efeitos}

$\mathrm{Na}$ trilha dos efeitos operados pelas pipas, pudemos flagrar, nos testemunhos dos nossos entrevistados e na literatura, aqueles que colocam este objeto no estatuto de um poderoso deslocador de ações, mobilizando:

Lembranças do passado:

[...] Nós chamamos os avós pra eles ajudarem na confecção e para soltar. Só que aí, só eles (referindo-se aos avós) brincaram, 'tadinhos'. Os meninos não gostaram e falaram pra não chamar mais não (risos). Era só eles que faziam, só eles que falavam, o chá ficou só pra eles. Então os meninos não quiseram que chamasse de novo não. Porque envolve! Teve um senhor que, quando começou a contar suas histórias com as pipas, [...] ele chorava com as lembranças. Era um apaixonado. Era tão apaixonado com as pipas quanto a gente (Trecho da entrevista com M.C., professora).

Emoções vividas durante um cruzo diante da incerteza de ainda poder continuar com a posse do brinquedo:

[...] Falando da emoção, uma coisa eu também percebi: todas as vezes que eu ia cruzar, o meu sangue e minha adrenalina disparavam. Eu não sei... Acho que é a sensação de risco que você corre. Até há uns dois ou três anos, quando eu ia cruzar, até o momento de uma linha tocar na outra, sem saber se eu ia voar ou ia cortar, a adrenalina e a pulsação iam lá em cima. Quando eu sentia que tinha voado, a adrenalina caia. Quando eu sentia que tinha cortado a outra, parece que a adrenalina durava mais um pouco. [...] Quando a gente vê aquela linha caindo e a meninada tentando pegar a linha, cada um tentando tirar um pedaço da linha da gente... Você não é mais dono. É, como se diz, uma posse passageira. Porque a pipa está lá no alto. Você pode cortar e você pode voar. E o que mais me deixava fascinado nessa história toda é que a pipa está lá em cima, você não sabe se você vai conseguir guardar ela de novo. Quanto mais você fica com ela no alto, você corta um, você corta dois, você não sabe quantos você vai cortar, ou se vocé é o próximo. É como se fosse uma roleta russa. Dificilmente alguém cortava ai uns oito ou nove e ainda conseguia ficar com a sua pipa. É muito dificil porque a linha começa a ficar puída, o outro cerol também já bateu na sua linha. Mais hora menos hora, sua pipa vai embora.

${ }^{18}$ É estimada uma quantidade de 20 mil pessoas para o público que comparece fiel ao Festival de Papagaios em Belo Horizonte.

Fractal, Rev. Psicol., v. 28 - n. 3, p. 341-350, 2016 
É uma probabilidade. Você ganhar todas na pipa é muito difícil. (Trecho da entrevista de P.A., funcionário público)

Não haverá mais profunda sensação de desamparo do que a desse momento doloroso em que um adversário, de cerol ou de arte mais aguçada, corta a tua linha - e lá se vai o teu papagaio, sozinho e perdido, levado pelo vento, vai cair lá longe, muitas vezes se afoga nas águas do rio. De repente abre-se um vácuo dentro de ti, a linha inerte e humilhada na tua mão: é como se tivesse decepado um pedaço da tua alma. (MELLO, 1983, p. 73)

Diante da expectativa da morte:

[...] Até mesmo na doença dele, quando ele imaginou que o caso dele pudesse ser cirúrgico com a expectativa de passar dois meses no hospital, ele já começou a providenciar material (vareta e papel) pra ter o que fazer dentro do hospital. Com menos intensidade, mas fazia as pipas. Não deixou de fazer nada. Fez a pipa até quando deu. Não desistiu de nada. Na verdade, ele não tinha medo de morrer. Ele não tinha medo nenhum. Ele só achava que era cedo demais. Ela achava que podia fazer muito mais coisas, ver os filhos dele crescerem. Se você está numa expectativa do que você não sabe o que vai acontecer, você apenas pressupõe, pelos casos que já existem, que vai acontecer de uma certa maneira, se você tiver muito tempo livre pra pensar, você acelera aquele processo. Então as pipas ajudaram muito a consumir o tempo dele em uma atividade útil (Trecho da entrevista com Ma, enfermeira).

Ou tendo a pipa como uma forma de terapia, como um efeito relaxante e apaziguador:

Com a pipa a gente se distrai. Quando você chega em casa, às vezes você chega cansado procurando um relaxamento [...] Se você vem de soltar pipa, você já chega em casa relaxado porque você não estava pensando em nada. É como se fosse uma terapia pra uma pessoa. Eu ouvi numa reportagem que agora tem uma terapia nos asilos em que eles usam os cachorros pra poder distrair os idosos porque eles são largados nos asilos sem os familiares procurarem eles. Então quem dá o carinho que eles precisam são os cachorros. A pipa seria mais ou menos isso. É tipo um abastecimento, entendeu? (Trecho da entrevista com Fo., estudante)

Como uma forma de agradecer aos céus:

Eu acho que tinha mais de cinqüenta criaturas em volta de mim, tinha até criança de colo, espiando eu empinar a estrela. Meu brinquedo estava preso no firmamento, grudado no ar. Mandei subir pela linha retesada um telegrama, que é como a gente chama uma rodela de papel crepom na direção do estirante. Foi muito divertido. As pessoas perguntavam como eu tivera a ideia de fazer aquela estrela. Então eu contava que estava alegre por causa de meu pai. Só isso. Ainda hoje, quem conhece minha cidade se lembra com encanto da minha estrela matutina, e há quem diga que, quando ela boiou no azul, todos se sentiram tocados pela alegria de um garoto empinador de estrelas (DIAFÉRIA, 1984, p. 33).

De retomar o gosto pela vida:

Mestre Antônio, sentado do lado de fora da cabana, terminava de fazer, com todo o capricho, a rabiola da pipa.
Assobiava uma velha canção do mar... À medida que ia dando forma de estrela ao brinquedo, ia se sentindo mais orgulhoso. Parecia que Mestre Antônio tinha um objeto de arte nas mãos [...] Sentia-se, também, mais jovem! Deixou até escapar uma exclamação:

- Ah! Que linda assim, a pipa [...] tão cheia de cores!

Mas, na verdade, era a vida de Mestre Antônio que voltava a ser colorida $[\ldots]$

Resolveu experimentá-la. Pouco a pouco foi soltando linha e a pipa voava e dançava no céu como se quisesse se exibir para seu criador! Olhando para o alto, o coração de Mestre Antônio também voava no azul do céu! (ALVES, M., 1992, cap. XIII, p. 37).

\section{Considerações Finais}

Tanto como híbrido sociotécnico ao qual delegamos funções e significados colocando nele parte de nossos anseios e necessidades, elo de uma imensa cadeia de mediadores que compõem a história da conquista aeroespacial, como na condição de objeto sagrado ao qual devotamos um culto que nos reintegra a um universo não mais cindido entre céu e terra, podemos entender a pipa como um fé(i)tiche.

Na lógica de Latour (2001), fetichismo seria delegar ações aos objetos, esquecendo o que há de humano neles. Num outro pólo, o antifetichismo seria a acusação de que os objetos não são nada, mas apenas uma projeção de humanos. Para ultrapassar essa dicotomia, poderíamos simplesmente admitir que o fé(i)tiche ou o fatiche é, ao mesmo tempo, a inclusão de humanos e não humanos na participação de um evento - mundo mental dos humanos e mundo físico das coisas - fazendo emergir uma fabricação. A mediação, antes exclusivamente humana, passa a ser estendida a outros atores que participam da ação, dadas as oportunidades que as circunstâncias oferecem. Nesta lógica, já não seríamos conduzidos a reducionismos e poderíamos levar em conta uma série de actantes, antes obscurecidos nas redes desordenadas e controvertidas que permitiam o aparecimento de um fenômeno.

Desta forma, entendemos a pipa como um fé(i)tiche inserido nas cadeias de mediadores de dois discursos: o da religião e o da ciência. Na cadeia de mediadores da ciência prestou-se a fazer a mediação técnica para o aparecimento de uma longa série de objetos que permitiram a conquista do espaço aéreo pelo homem. Na cadeia de mediadores da religião, evoca uma ligação perdida entre o céu e a terra que torna mágico o movimento de sua ascensão, produzindo não só efeitos de encantamento, mas outros que funcionam como verdadeiros deslocadores de ações.

\section{Referências}

ALVES, M. D. G. Amigos para sempre. Belo Horizonte: Ed. Lê, 1992.

ALVES, R. A pipa e a flor. São Paulo: Loyola, 1986.

ARIÈS, P. A história social da criança e da família. Rio de Janeiro: Guanabara Koogan, 1981. 
AUGÉ, M. O fetiche e seu objeto: abordagem etnológica. In: AUGÉ, M. et al. (Org.) O objeto em psicanálise: o fetiche, o corpo, a criança, a ciência. Campinas: Papirus, 1989. p. 42-60.

BENJAMIN, W. Reflexões: a criança, o brinquedo, a educação. São Paulo: Summus, 1984.

BROUGÈRE, G. Brinquedo e cultura. São Paulo: Cortez, 2000.

DIAFÉRIA, L. O empinador de estrela. São Paulo: Moderna, 1984.

ELIADE, M. Mitos, sonhos e mistérios. Lisboa: Ed. 70. 1957.

ELIADE, M. Mefistófeles e o andrógino. São Paulo: Martins Fontes, 1991.

EQUIPE SILVIO VOCE. Empresa de promoções e eventos, que realiza atividades variadas em todo o Brasil, e ficou muito conhecida por suas atividades com PIPAS e PAPAGAIOS. Disponível em: <http://www.pipas.com.br/>. Acesso em: 12 jun. 2013.

FATO. In: FERREIRA, A.B. H. Novo Dicionário Aurélio da Lingua Portuguesa. Rio de Janeiro: Nova Fronteira, 1986. p. 614.

FEITIÇO. In: FERREIRA, A.B. H. Novo Dicionário Aurélio da Lingua Portuguesa. Rio de Janeiro: Nova Fronteira, 1986. p. 619 .

FETICHE. In: FERREIRA, A.B. H. Novo Dicionário Aurélio da Língua Portuguesa. Rio de Janeiro: Nova Fronteira, 1986. p. 623 .

KEN YAMAZATO (Site). Engenheiro mecânico, é apaixonado por pipas/papagaios desde criança, e por toda a vida tem se dedicado ao estudo e à arte de projetar e criar modelos das mais variadas cores, tamanhos e formatos. Disponível em: <http:// www.kenyamazato.com.br/>. Acesso em: 22 jun. 2013.

KENT, S. The creative book of kites. New York: Smithmark Books, 1997.

LATOUR, B. As visões do Espírito: uma introdução a antropologia das ciências e das técnicas. Culture Technique, $\mathrm{n}$. 14 p. 5-29, 1985. Traduzido para Publicações didáticas, mar. 1990, por J. M. Carvalho de Mello e C. J. Saldanha Machado.

LATOUR, B. A esperança de Pandora. Bauru, SP: EDUSC, 2001.

LATOUR, B. Reflexão sobre o culto moderno dos deuses fé(i) tiches. Bauru, SP: EDUSC, 2002a.

LATOUR, B. Another take on the science and religion debate. 2002b. Disponível em: <http://www.bruno-latour.fr/ node/167>. Acesso em: 23 maio 2013.

MARX, K. O Capital. São Paulo: Abril Cultural, 1983.

MELLO, T. Arte e ciência de empinar papagaio. Rio de Janeiro: Civilização Brasileira, 1983.

PIPA. In: DICIONÁRIO da Enciclopédia Mirador. Antônio Houaiss, ed. São Paulo: Encyclopaedia Britannica do Brasil, 1979. p. 1272.

PORTAL das pipas. (Site). Disponível em: <http://www. portaldaspipas.com.br/>. Acesso em: 21 jun. 2013.

RIOS, J. A. Pipas, papagaios e pandorgas. Carta Mensal, Rio de Janeiro, v. 49, n. 582, p. 3-27, 2003.

SEBEOK, T. A. Fetiche. Face, S. Paulo, vol. 1, n. 2, p. 11-25, 1988.
SERRES, M. Filosofia mestiça. Rio de Janeiro: Nova Fronteira, 1993.

VOCE, S. Brincando com pipas múltiplas e de duplo comando. São Paulo: Global, 2002.

Recebido em: 17 de julho de 2013

Aceito em: 11 de outubro de 2016 